\title{
Woody plant species diversity as a predictor of ecosystem services in a social-ecological system of southwestern Ethiopia
}

\author{
Girma Shumi · Patrícia Rodrigues · Jan Hanspach • Werner Härdtle • \\ Kristoffer Hylander $\cdot$ Feyera Senbeta $\cdot$ Joern Fischer $\cdot$ Jannik Schultner
}

Received: 28 March 2019/Accepted: 19 November 2020/Published online: 4 December 2020

(C) The Author(s) 2020

\begin{abstract}
Context Human-dominated landscapes in the tropics need to be managed for biodiversity and the maintenance of ecosystem services (ES). Nevertheless, integrating both biodiversity conservation and ES management remains a challenge.

Objectives This study aimed to quantify woody plant species diversity and associated ES in farmland and forests, and investigate the relationship between species and ES diversity.

Methods The study was conducted in southwestern Ethiopia. We surveyed woody plants in $18120 \mathrm{~m}$ by $20 \mathrm{~m}$ plots in farmland, forest with, and forest without coffee management. We also interviewed 180 ran-
\end{abstract}

Supplementary Information The online version contains supplementary material available at https://doi.org/10.1007/ s10980-020-01170-x.

\section{G. Shumi $(\bowtie) \cdot$ P. Rodrigues · J. Hanspach ·}

W. Härdtle · J. Fischer · J. Schultner

Faculty of Sustainability, Leuphana University,

Universitaetsallee 1, 21335 Lüneburg, Germany

e-mail: girmasd@gmail.com

P. Rodrigues

e-mail: patricia.rodrigues@leuphana.de

J. Hanspach

e-mail: hanspach@leuphana.de

W. Härdtle

e-mail: haerdtle@uni-lueneburg.de

J. Fischer

e-mail: joern.fischer@leuphana.de domly selected households about woody plant benefits. We then (a) quantified species and ES diversity; and (b) investigated the relationship between species and ES diversity.

Results We recorded 128 woody plant species in total. Most ES were available in all land uses, although they differed in their mean availability. ES composition was significantly different among land uses. ES diversity was positively related with species diversity in all land uses.

Conclusions Our findings suggest that all examined land-use types were multifunctional in terms of key ES provided by woody plants and that maintaining high species diversity also benefits ES diversity. Given these findings, we suggest to: (1) strengthen landscape multifunctionality by drawing on the positive relationship between biodiversity and ES diversity; (2) devise conservation policies that encompass entire

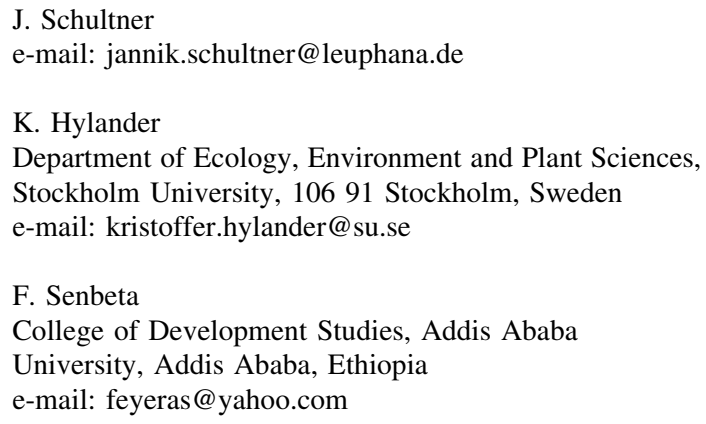


landscape mosaics and enhance co-benefits of conservation and ES provision across land uses; and (3) conduct further social-ecological studies that use mixed data to elicit socially relevant relationships between biodiversity and ES diversity.

Keywords Biodiversity conservation - Ecosystem service diversity · Human wellbeing $\cdot$ Land management - Landscape sustainability · Multifunctionality

\section{Introduction}

The ecosystem service (ES) framework has become an important tool to link biodiversity conservation and human wellbeing (Díaz et al. 2015), especially since the Millennium Ecosystem Assessment (MA 2005). A fundamental tenet of this framework is that biodiversity is positively related to the provision of ES and thereby benefits human wellbeing (Peterson et al. 1998; Isbell et al. 2011; Brockerhoff et al. 2017). Biodiversity generates supporting (e.g. nutrient cycling), provisioning (e.g. food, fuel, and timber), regulating (e.g. climate regulation) and cultural (e.g. spiritual experience) ES (MA 2003; Díaz et al. 2018). It is also key to ecosystem resilience, i.e. the capacity to absorb shocks and continue functioning (Folke et al. 2004).

Understanding the relationships between biodiversity and ES has become a major field of research (Peterson et al. 1998; Isbell et al. 2011; Cardinale et al. 2012). However, empirical studies that examine how biodiversity relates to the provision of multiple ES in different land-use types across real landscapes remain scarce (Mitchell et al. 2015; Brockerhoff et al. 2017; Manning et al. 2018). With the exception of some theoretical and experimental explorations (e.g. Maestre et al. 2012; Gamfeldt et al. 2013; Allan et al. 2015), few studies have systematically examined biodiversity-ES relationships across gradients of land-use intensity within human-modified landscapes (e.g. Woollen et al. 2016; Rasmussen et al. 2018), which is arguably where such relationships matter most (e.g. Jönsson and Snäll 2020). Additionally, most studies on the relationship between biodiversity and ES have considered the effects of species diversity on individual ES (Schwartz et al. 2000; Cardinale et al. 2012;
Lefcheck et al. 2015), despite the fact that many landscapes are managed for multiple ES (Hector and Bagchi 2007; Eigenbrod 2016). In some instances, studies have also suffered from a disparity between the assessed ES and the actual ES required by people in a specific landscape (Balvanera et al. 2014; Woollen et al. 2016; Díaz et al. 2018). As a result, important aspects of biodiversity and multiple ES in a given landscape may be overlooked, with potential negative repercussions for the effective conservation and management of ES (Gamfeldt et al. 2008; Wu 2013; Eigenbrod 2016).

Humans, particularly in less developed countries, directly rely on the ES generated by a biodiverse environment for their livelihoods (Shackleton et al. 2011; Sunderland et al. 2013; Reed et al. 2017). Especially, woody plants provide many important services, which are directly or indirectly associated with particular species (Díaz et al. 2006; Shackleton et al. 2011; Rasmussen et al. 2017). For example, between 1.3 and 2.4 billion people use wood for house construction and cooking (FAO 2014), and 1.4-1.6 billion people use non-timber forest products for their livelihoods and cultural needs (Shackleton et al. 2011).

The link between biodiversity and wellbeing is particularly strong for smallholder farmers (Rasmussen et al. 2017; Reed et al. 2017; Ahammad et al. 2019), who typically are part of tightly coupled social-ecological systems (Berkes et al. 2003; Folke 2006; Fischer et al. 2012). Smallholder farming often produces multifunctional landscapes because farmers manage their land to foster the generation of a diverse portfolio of ES, or ES multifunctionality (O'Farrell and Anderson 2010; Sunderland 2011; Manning et al. 2018). Multifunctional landscapes are found worldwide (Sunderland 2011; Tscharntke et al. 2012); examples are agroforestry systems in which coffee and cacao are grown under shade trees in Africa, Latin America and Asia (Perfecto et al. 2007; Perfecto and Vandermeer 2010; Tscharntke et al. 2011), or traditional wood-pasture systems in eastern Europe (Hartel et al. 2013).

The global shift to production-oriented land-use policies and management practices has resulted in the simplification of multifunctional landscapes, with various consequences for biodiversity conservation and human wellbeing (de Groot et al. 2010; RaudseppHearne et al. 2010a; Rasmussen et al. 2018; Neyret 
et al. 2020). Many agricultural landscapes have been pushed towards increasingly intensive practices (Tilman et al. 2001; Foley et al. 2005; Ramankutty et al. 2008), favouring the production of high-yielding crops but paying little attention to other potentially important ES (Tscharntke et al. 2012; DeClerck et al. 2016; Rasmussen et al. 2018). Although sufficient agricultural yields are critical for human wellbeing, the loss of numerous ES not associated with crops could eventually have major negative ramifications for poor people (Rahman et al. 2015; DeClerck et al. 2016; Rasmussen et al. 2018). Especially in the light of globally changing environmental conditions, which threaten ecosystem integrity and functioning (e.g. Isbell et al. 2015; Hisano et al. 2018), maintaining biodiverse and multifunctional landscapes is critically important to mitigate ecological and social impacts. Finding management strategies for landscapes that foster both biodiversity and the ongoing supply of diverse ES is therefore a key sustainability challenge.

In this study, we investigated the relationship between woody plant species diversity and ES diversity across different land-use types within a smallholder-dominated farming landscape in southwestern Ethiopia. In the region, while the landscape harbours a high diversity of woody plant species that provide key services for local people (e.g. Jara et al. 2017; Shumi et al. 2018, 2019b), current agricultural policies favour agricultural intensification (e.g. Kassa et al. 2016) and thus negatively impact woody plant species diversity and associated ES. At present, local people depend on multiple ES provided by different woody plant species for their day-to-day livelihoods (Ango et al. 2014; Dorresteijn et al. 2017; Shumi et al. 2019a). To explore how woody plant species diversity was related to ES diversity in the landscape, we collected social data on local people's benefits obtained from different woody plant species. We then linked this data with ecological field data on the presence, abundance and size of woody plant species occurring in farmland (arable land and grazing land) and forests (with and without coffee management).

Our aims were to (i) quantify woody plant species diversity and their associated ES supply, and evaluate ES composition in different land uses, namely farmland, forest with coffee management and forest without coffee management; and (ii) investigate the relationship between woody plant species diversity and ES diversity in all three land-use types. We hypothesized that different land-use types provide diverse ES, that ES composition varies among landuse types, and that ES diversity is positively related to woody plant species diversity.

\section{Methods}

Study area

The study was conducted in a smallholder-dominated landscape, within which we focused on six kebeles (the smallest administrative unit in Ethiopia) located in the Gera, Gumay and Setema districts of Jimma Zone, Oromia Regional State, southwestern Ethiopia (Fig. 1). The study kebeles comprised a mosaic of land-use types, with forest cover ranging from 11 to $84 \%$, while arable land, grazing land and settlements accounted for the rest.

The natural vegetation in the study area has been classified as moist evergreen Afromontane forest (Friis et al. 2010). Dominant tree species in the forest include Olea welwitschii, Pouteria adolfi-friederici, Schefflera abyssinica, Prunus africana, Albizia spp., Syzygium guineense, and Cordia africana (Cheng et al. 1998). The study area is part of the centre of origin of Coffea arabica, and still harbours the gene pool of wild coffee populations (Anthony et al. 2002). It is also a part of the Eastern Afromontane Biodiversity Hotspot (Schmitt 2006; Mittermeier et al. 2011). The study area comprises undulating slopes and flat plateaus, with elevation ranging from 1500 to $3000 \mathrm{~m}$ above sea level. It has a warm moist climate within the inter-tropical convergence zone, with 1500-2000 mm of annual rainfall, and a $20{ }^{\circ} \mathrm{C}$ mean annual temperature. Annual rainfall patterns are unimodal, with a wet season peak from June to September (Friis et al. 2010; Schmitt et al. 2013; Ango 2016).

All land, including forest, is owned by the government (FDRE 1995) and local communities have limited use rights (Crewett et al. 2008). Customary forest use rights are also in place in some locations to manage forest for honey and coffee production (Wakjira and Gole 2007). Smallholder-agriculture based on crop production and livestock breeding is the main source of livelihoods. Coffee and to a lesser degree honey are economically important non-timber forest products in the area. The human population of the study kebeles ranged from 3230 to 9975 people per 
(a)

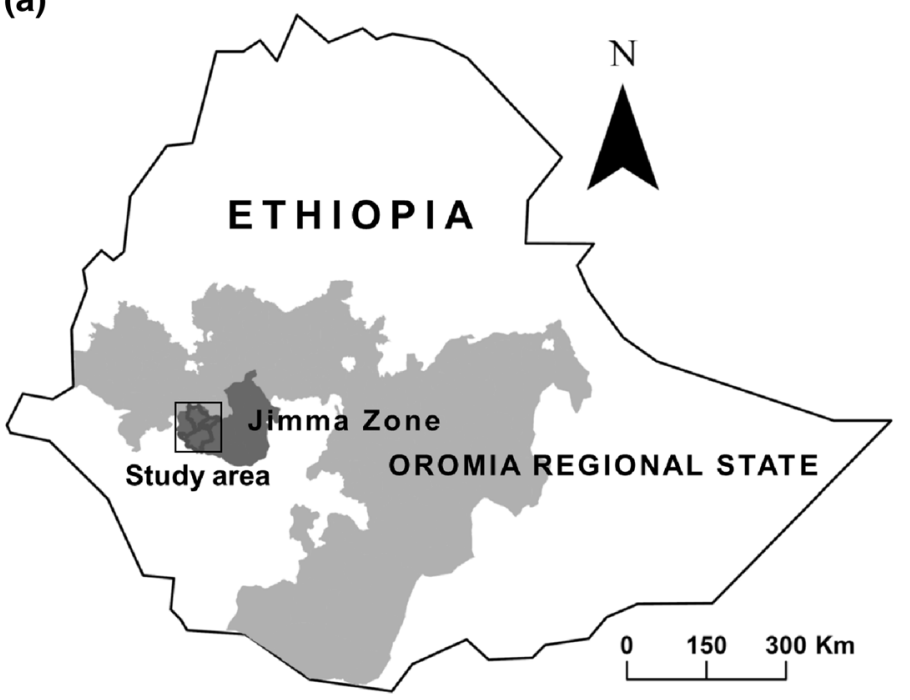

(b)

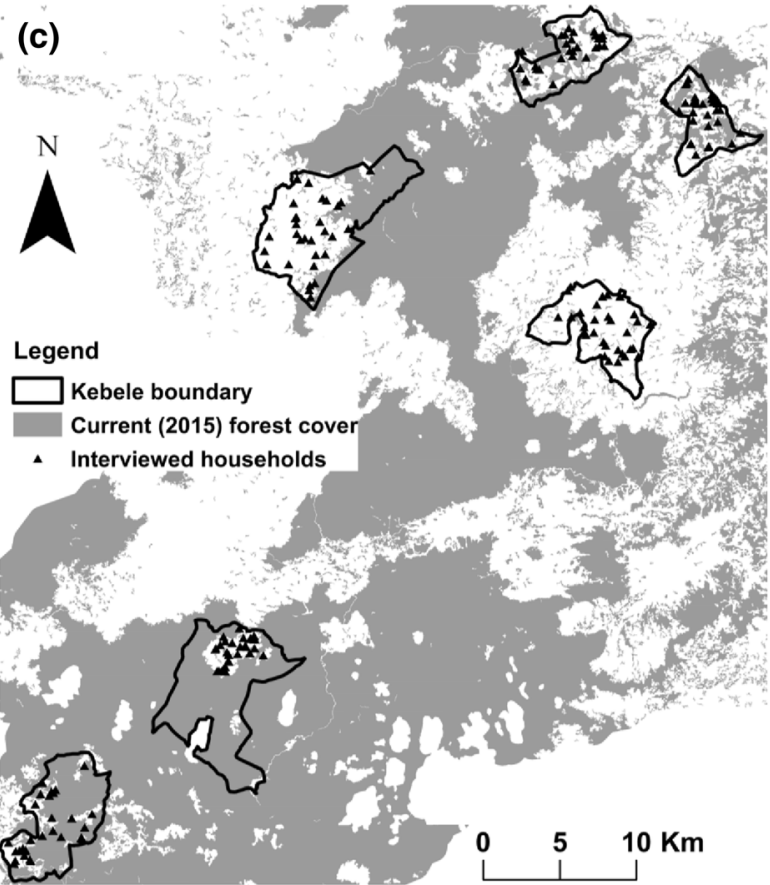

Fig. 1 a Study area (square) in Jimma Zone, Ethiopia; b the six kebeles: Difo Mani and Gido Bere in Setema district, Bere Weranigo and Kuda Kofi in Gumay, and Borcho Deka and Kela Harari in Gera; c interviewed households (black triangles); and

kebele (Dorresteijn et al. 2017). The largest ethnic group in the study area is the Oromo, while Amhara, Kefficho and Tigre people are minorities (see Table S1; Shumi et al. 2019a). (d)

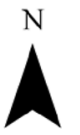

Legend

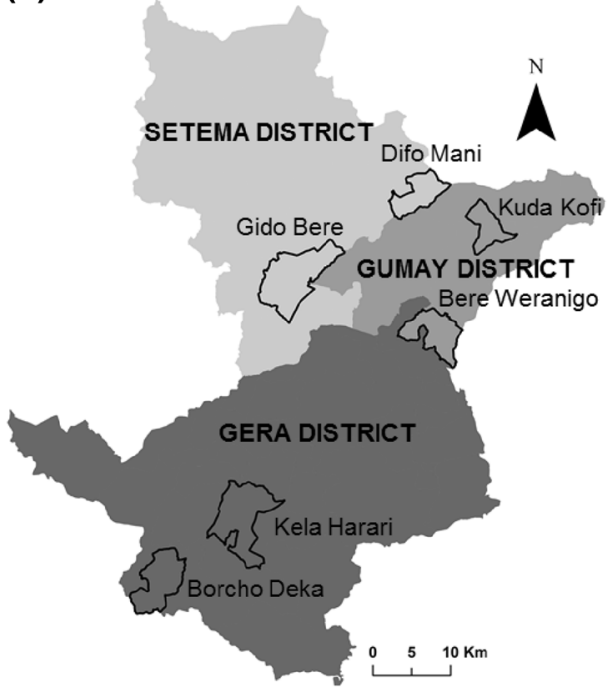

Kebele boundary

Current (2015) forest cover

- Farmland sites

+ Forest sites with coffee management

$\times$ Forest sites without coffee management

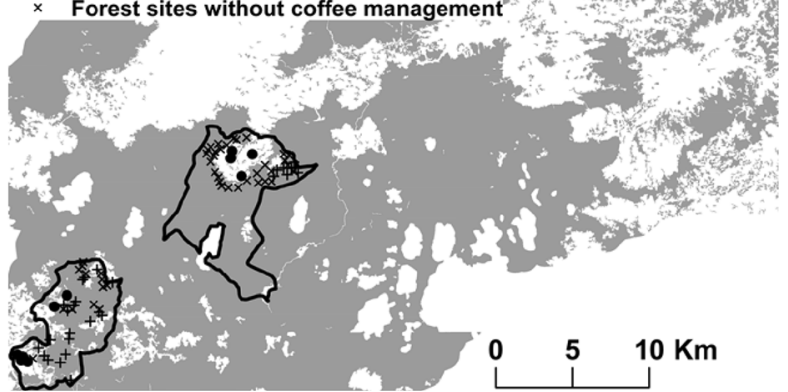

d woody plant survey points: in farmland (black circles), in forest with coffee management ("+" sign), and in forest without coffee management (" $\mathrm{x}$ " sign). In $\mathbf{c}$ and $\mathbf{d}$ grey colour represents current forest cover

Data collection

Woody plant survey

We surveyed woody plants from November 2015 to January 2016, and from April to May 2017. Prior to 
woody plant surveys, using ArcGIS 10.2, we determined the proportion of farmland and forest within each kebele using a land cover map generated via supervised image classification of a RapidEye satellite image from 2015.

For farmland, we determined the proportion of arable land and grazing land and then, we randomly selected 72 circular 1 ha survey sites across the six kebeles -53 in arable land and 19 in grazing land, assigned proportionally to the occurrence of arable land and grazing land in each kebele. To be able to directly compare woody plant data from farmland with forest data (described below), we laid a $20 \mathrm{~m}$ by $20 \mathrm{~m}$ subplot at one of the edges of the focal 1 ha circular site, in the first instance in a northerly direction; or if there was no woody vegetation cover in the northern direction, to the east, south or west.

For forest sites, to capture possible gradients of human disturbance, we stratified the forest into four cost distance classes (low, medium, high and very high cost distance), using the cost distance analysis tool in ArcGIS. Finally, we randomly selected a total of 109 , $20 \mathrm{~m}$ by $20 \mathrm{~m}$ plots (46 in forests with coffee management and 63 in forests without coffee management), distributed across the six kebeles and across the four cost distance classes (30 in low, 21 in medium, 20 high, and 38 very high cost distance). In total, we thus obtained $18120 \mathrm{~m}$ by $20 \mathrm{~m}$ plots (72 in farmlands, 46 in forests with coffee management and 63 in forests without coffee management) distributed across the six kebeles (22-42 plots per kebele) and spanning a broad range of environmental conditions (Fig. 1).

In each plot, all individuals of tree and shrub species with a height $\geq 1.5 \mathrm{~m}$ were recorded. We also measured the diameter at breast height (DBH) of all individuals with $\mathrm{DBH} \geq 5 \mathrm{~cm}$. For species that were difficult to identify in the field, specimens were collected, pressed, dried and transported to the National Herbarium at Addis Ababa University for identification. Nomenclature follows the Flora of Ethiopia and Eritrea (1989-2006).

\section{Household survey}

Social data were collected through a household survey from February to March 2017. We interviewed 180 randomly selected households and assessed the use and preference of woody plant species for 11 purposes.
These purposes were: fuelwood, fencing material, farm implements, honey production, house construction, household utilities, poles and timber, medicine, animal fodder, shade for coffee cultivation, and soil fertilisation. The selection of these purposes was based on a pilot study and existing literature (Wakjira and Gole 2007; Ango 2016). Local people sourced these benefits from farmland (mainly arable land and grazing land), and forests (with and without coffee management). For details of methods, such as the characteristics of respondents and sources of woody plants, see Shumi et al. (2019a) and Table S1.

\section{Data on ES}

To generate data on ES, we combined the ecological and social data collected. Specifically, we used (1) woody plant species presence, abundance and DBH recorded per plot; (2) the list of woody plant species reported to be used for each purpose, inferred from household surveys (see Table S2); and (3) reasonable diameter thresholds, that is, the minimum size an individual woody plant species needs to attain to be useful for a particular purpose (e.g. an individual of a species needs to attain $\geq 5 \mathrm{~cm}$ DBH to be useful for house wall and roof construction; Table 1).

Using this information, we developed a woody plant species-ES presence matrix, and determined the potential ES available in each plot surveyed for woody vegetation. In this matrix, we assigned " 1 " in the column of a given purpose (hereafter ecosystem service) for an individual of a species present in a given plot, if (a) the species was reported to be used by local people for that service, and (b) the individual of this species met the size threshold criteria for service; we otherwise assigned " 0 " if these criteria were not fulfilled. For example, a survey plot may have had three individuals of $C$. africana (e.g. one with $5 \mathrm{~cm}$ $\mathrm{DBH}$, one with $9 \mathrm{~cm}$, and one with $20 \mathrm{~cm}$ ). We knew from the household survey that $C$. africana was used by local people for poles and timber (as well as other ES; see Table S2); and we had set a size threshold of $10 \mathrm{~cm} \mathrm{DBH}$ for species to be useful as "poles and timber". Hence, in this case, we noted two times " 0 ", and one time " 1 " in the column "poles and timber" for C. africana in this plot (i.e. only one individual fulfilled the criteria for the ES poles and timber). Cordia africana was also used for the ES "fuelwood" (Table S2), but without a size threshold (Table 1). We 
Table 1 List of uses of woody plants, including description and threshold size

\begin{tabular}{|c|c|c|c|}
\hline Use/purpose & & Description & Threshold \\
\hline \multirow{2}{*}{$\begin{array}{l}\text { House } \\
\text { construction }\end{array}$} & House wall and roof construction & Wood used for wall and roof construction & $\mathrm{DBH} \geq 5 \mathrm{~cm}$ \\
\hline & Wall and roof fixing & Small wood used for fixing wall and roof & $\begin{array}{l}\text { Any size (can be } \\
\text { split) }\end{array}$ \\
\hline \multirow{3}{*}{$\begin{array}{l}\text { Farm } \\
\text { implements }\end{array}$} & Handle & Wood used as beam handle for ploughing & DBH $5-10 \mathrm{~cm}$ \\
\hline & Yoke & Wood used as yoke for ploughing & DBH $10-30 \mathrm{~cm}$ \\
\hline & Beam & Wood used as beam for ploughing & $\begin{array}{l}\text { DBH } 10-20 \mathrm{~cm} \\
\text { (can be prepared) }\end{array}$ \\
\hline Fuelwood & Firewood and charcoal & $\begin{array}{l}\text { Parts (leaf, bark or wood) of trees/shrubs used } \\
\text { for cooking, lighting and heating }\end{array}$ & $\begin{array}{l}\text { Any size (can be } \\
\text { split) }\end{array}$ \\
\hline \multirow[t]{5}{*}{$\begin{array}{l}\text { Honey } \\
\text { production }\end{array}$} & Beehive making & $\begin{array}{l}\text { Small wood used for making or fixing the wall } \\
\text { of beehives }\end{array}$ & $\mathrm{DBH}<5 \mathrm{~cm}$ \\
\hline & & Wood or bark used for making beehives & $\begin{array}{l}\mathrm{DBH}>20 \mathrm{~cm}(\mathrm{can} \\
\text { be prepared })\end{array}$ \\
\hline & Beehive hanging & $\begin{array}{l}\text { Intermediate and large/old trees/shrubs } \\
\text { preferred for beehive hanging }\end{array}$ & $\mathrm{DBH}>20 \mathrm{~cm}$ \\
\hline & Bee forage & Shrub/small trees suitable for bee forage & Any size \\
\hline & & Large/old trees suitable for bee forage & $\mathrm{DBH}>10 \mathrm{~cm}$ \\
\hline \multirow[t]{2}{*}{ Fence } & Live fence & Living trees/shrubs serving as fence & Any size \\
\hline & Dead wood fence & Wood used for fencing & Any size \\
\hline Medicine & & $\begin{array}{l}\text { Parts (leaf, bark or wood) of trees/shrubs used } \\
\text { for healing human or animals }\end{array}$ & Any size \\
\hline \multirow[t]{2}{*}{ Coffee shade } & & $\begin{array}{l}\text { Small planted trees/shrubs providing coffee } \\
\text { shade }\end{array}$ & $\mathrm{DBH} \geq 5 \mathrm{~cm}$ \\
\hline & & $\begin{array}{l}\text { Retained or planted trees/shrubs that can serve } \\
\text { as coffee shade }\end{array}$ & $\mathrm{DBH}>10 \mathrm{~cm}$ \\
\hline $\begin{array}{l}\text { Household } \\
\text { utilities }\end{array}$ & & $\begin{array}{l}\text { Wood used to make small household utilities } \\
\text { or tools }\end{array}$ & $\mathrm{DBH}>10 \mathrm{~cm}$ \\
\hline $\begin{array}{l}\text { Soil } \\
\text { fertilisation }\end{array}$ & & Trees/shrubs contributing to soil fertilisation & Any size \\
\hline $\begin{array}{l}\text { Animal } \\
\text { fodder }\end{array}$ & & $\begin{array}{l}\text { Parts (leaf, twigs or bark) of trees/shrubs used } \\
\text { as animal fodder }\end{array}$ & Any size \\
\hline $\begin{array}{l}\text { Poles and } \\
\text { timber }\end{array}$ & & Wood used for poles and timber & $\mathrm{DBH} \geq 10 \mathrm{~cm}$ \\
\hline
\end{tabular}

This list was used to determine the ES provided in each survey plot. Note that only suitable tree/shrub species were considered for each purpose

thus noted three times " 1 " in the fuelwood column for this species in this plot (i.e. all individuals fulfilled the criteria for the ES fuelwood). We followed this procedure for every individual of every woody species recorded in each plot, for each of the $11 \mathrm{ES}$ considered. Summing the individuals in a given plot for a given service thus gave the number of individual woody plants that provided a particular ES in a given plot (see also de Groot et al. 2010; Burkhard et al. 2012). This way, we determined the potential ES provisioning of a given plot, rather than the actual provisioning-for example, a plot with a lot of firewood present may not actually be used for firewood collection; and a plot with a lot of coffee shade trees may not actually be used to provide shade for coffee plants. 
Data analysis

The analysis followed three steps. First, we quantified woody plant species diversity in different land-use types. Second, we quantified and examined ES composition patterns in farmland, forest with and without coffee management. Third, we investigated woody plant species diversity-ES diversity relationships in the three land-use types.

\section{Woody plant species diversity}

We first determined key aspects of species diversitythat is, species richness (i.e. the number of species present) and the Shannon diversity index (an index that accounts for both the number of species present, i.e. species richness, and the abundance of individuals per species), for all plots in each land-use type (Lande 1996; Spellerberg and Fedor 2003). Second, we illustrated the cumulative species richness within a land-use type using plot-level species accumulation curves. Finally, to increase the scale of our inference beyond the plot level to the landscape level, we calculated Simpson's alpha, beta (additive) and gamma diversities as well as turnover, i.e. spatial differences in diversity measured by Bray-Curtis dissimilarity distances, of woody plant species in each land-use type. The indices were calculated based on the above-described surveys in $20 \mathrm{~m}$ by $20 \mathrm{~m}$ plots. Analyses were done using the 'vegan' package (Oksanen et al. 2019) and the 'betapart' package (Baselga et al. 2018) in R (R Core Team 2019).

\section{ES diversity}

Here, we first determined the potential supply of each ES from the woody plant species-ES matrix (see above) for each survey plot. Second, we standardized each ES to values between 0 and 1 by dividing the abundance of a given ES in a given plot by its maximum abundance found within the entire study area (i.e. across all land-use types). We then determined the mean extent of each ES provided by each land-use type. Third, we ran a non-metric multidimensional scaling ordination (NMDS, with BrayCurtis dissimilarity distance, 999 permutations) and a permutational multivariate ANOVA using the Adonis function in the 'vegan' package (Oksanen et al. 2019) in $\mathrm{R}$ ( $\mathrm{R}$ Core Team 2019) to visualize patterns of ES composition and test for possible differences in ES composition among land-use types in the landscape. Fourth, we calculated Simpson's alpha, beta and gamma diversities and turnover of ES for each landuse type using the same approach as described for the species diversity above.

\section{Relationship between biodiversity and ES diversity}

Prior to modelling, we determined the total number of ES and the 'ES Shannon diversity index' for each plot, which we considered as a proxy for the ES multifunctionality of a given plot (e.g. Fagerholm et al. 2012; Plieninger et al. 2013; Manning et al. 2018). We then calculated the Spearman rank correlation between the total number of ES in a given plot and the plot's ES Shannon diversity. The two measures of ES diversity were highly correlated (0.75), and therefore both provided meaningful indices of the potential multifunctionality of a given plot. We chose ES Shannon diversity as a response variable for modelling because it was a continuous variable, and therefore had a finer data resolution than the total number of ES. We also checked for possible correlations/trade-offs between all 11 different ES using Spearman correlation methods and found no evidence for obvious trade-offs among ES (Table S3 and Fig. S1).

We then used linear mixed effects models with a Gaussian error distribution structure to investigate the relationship between: (i) ES Shannon diversity in response to woody plant species richness, and (ii) ES Shannon diversity in response to woody plant species Shannon diversity. In both cases, we also fitted landuse type as an additional explanatory variable, as well as the interactions between land-use type and species richness or species Shannon diversity, respectively. We log-transformed the variable species richness to account for its skewed distribution. We used 'kebele' as a random factor in the models to account for grouping in experimental units. We also checked, but found no evidence, for possible spatial autocorrelation of residuals of each model using Moran's I method ( $p=0.304$ for species richness model, and $p=0.275$ for the model of Shannon diversity of species). Finally, to visualise the modelled relationships, we predicted and plotted ES Shannon diversity values and their $95 \%$ confidence intervals in response to species richness and species Shannon diversity for each landuse type. 


\section{Results}

Woody plant diversity

We identified 128 woody plant species (with one unidentified specimen at species level and six planted exotic species) in total, representing 43 families in the 181 plots analysed (Table S4). Of these, Vernonia auriculifera, Erythrina brucei and Croton macrostachyus were the most abundant species in farmland; Coffea arabica, Maytenus arbutifolia and Vernonia auriculifera were abundant in forest with coffee management; and Dracaena afromontana, Chionanthus mildbraedii and Justicia schimperiana were the most common species in forest without coffee management (Table S4). Of all species, $11 \%$ occurred exclusively in farmland, $10 \%$ in forest without coffee management and $7 \%$ in forest with coffee management (Fig. 2a); and $72 \%$ occurred in more than one land-use type (Fig. 2a). Species accumulation curves illustrated that forests with and without coffee management had higher species diversity than farmland and had a similar increase in cumulative species richness (Fig. 2b). Farmland plots had a more gradual increase in cumulative species richness than forests (Fig. 2b). These richness patterns were confirmed by our analysis of Simpson's alpha and gamma diversity, though some of the differences in gamma diversity may be driven by lower sample size especially in forest with coffee management (Table 2). When considering the diversity in community composition, i.e. the various proportions of different species (beta diversity) and the species replacement between plots across the landscape (species turnover), we found farmland to be especially diverse (Table 2).

\section{Composition of ES in different land uses}

Almost all ES were provided by all land-use types, although their mean values differed (Fig. 3). Mean provisioning of house construction, fuelwood, and honey production ES were highest in forest with coffee management, while household utilities, potential coffee shade species, fencing materials and poles and timber ES were most readily available in forest without coffee management (Fig. 3) (evidently, potential coffee shade species were not actually used for coffee cultivation in this environment). Conversely, mean provisioning of soil fertilisation, fencing materials, and medicine ES were higher than other services in farmland. Mean values of all ES were much lower in farmland than in forests (Fig. 3), which might be caused by the overall lower species richness and abundance of woody plant species in farmland (Fig. 2b; Fig. S2; and Table S5).

Non-metric multidimensional scaling (NMDS, two dimensional ordination; stress $=0.114$ ) showed ES composition differed among land-use types, and was particularly variable within the group of farmland plots (Fig. 4). This difference in ES composition between the land-use types was significant (permutation analysis of variance: $F_{2,178}=46.13, p<0.001$ ). The potential ES supply of soil fertilisation and medicine were particularly pronounced in farmland; fuelwood, house construction and honey production in forest with coffee management; and animal fodder, household utilities and poles and timber in forest without coffee management (Fig. 4). ES Simpson's alpha and gamma diversities were higher in forests (Table 2), while farmland was particularly diverse in terms of ES beta diversity and turnover between sites across the landscape (Fig. 4; Table 2).

Relationships between ES diversity and woody plant species diversity

ES diversity was positively related to woody plant species diversity in all land-use types (Table 3; Fig. 5a, b). However, there were also significant interaction effects between land-use type and both species richness and species Shannon diversity (Table 3). ES Shannon diversity significantly increased with species richness in farmland and in forest with coffee management, but, for low values of species richness, farmland had lower ES diversity (Table 3; Fig. 5a). ES diversity in farmland appeared to decrease sharply when species richness dropped below ten species. Similarly, ES Shannon diversity significantly increased with species Shannon diversity in all land-use types, but more sharply in farmland than in forests (Table 3; Fig. 5b). ES diversity thus increased relatively slowly in forests, and more sharply in farmland in response to both species richness and Shannon diversity of species (Fig. 5a, b). At higher species richness and diversity, ES diversity across land-use types was similar (Fig. 5a, b). 


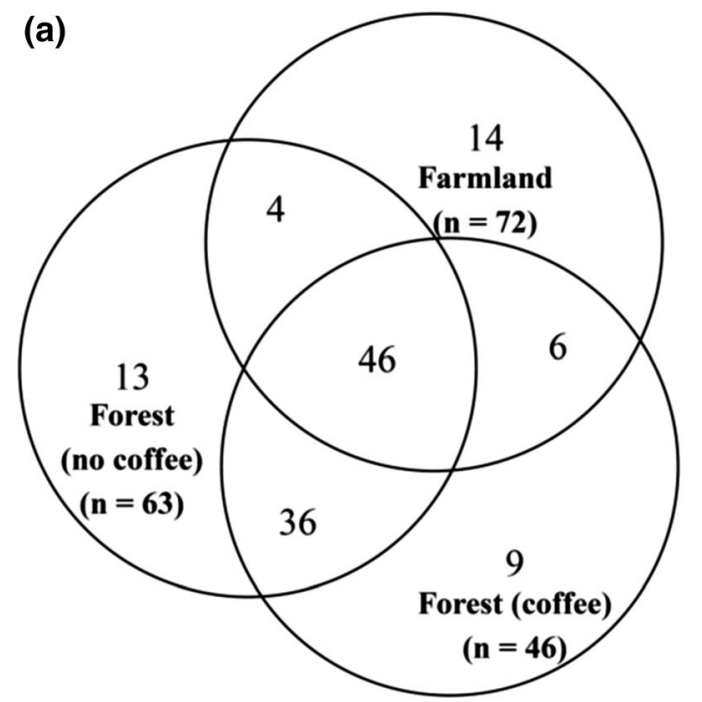

Fig. 2 a Number of woody plant species occurred exclusively in or was shared by the different land-use types, namely, farmland, forest $($ coffee $)=$ forest with coffee management, and

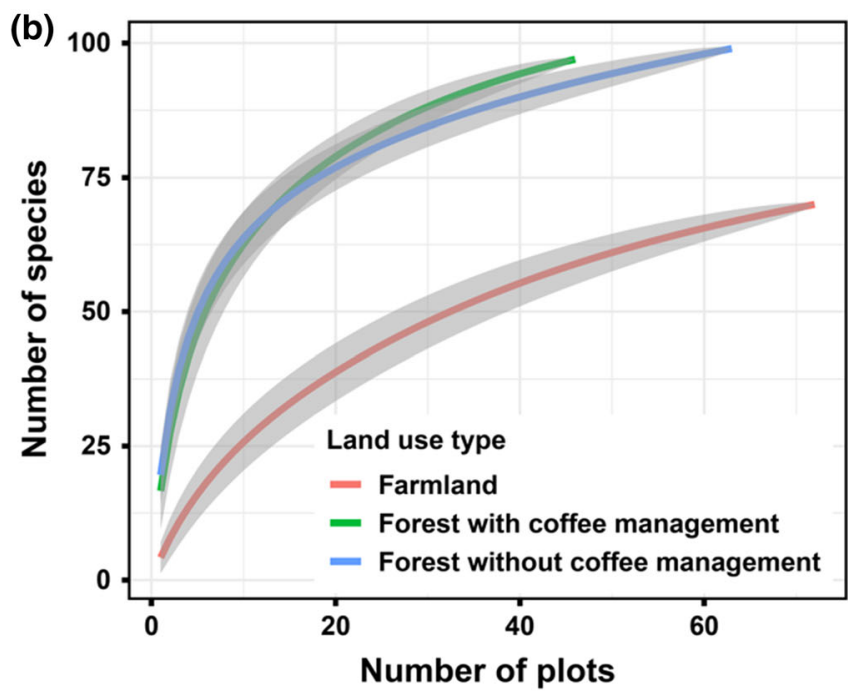

forest $($ no coffee $)=$ forest without coffee management . b Species accumulation curves in the three land-use types, where shaded areas indicate $95 \%$ confidence intervals

Table 2 Alpha, beta, and gamma diversity indices, and Bray-Curtis dissimilarity distances as a measure of turnover of woody plant species and ES for the three focal land-use types in the landscape

\begin{tabular}{|c|c|c|c|c|}
\hline & \multicolumn{3}{|c|}{ Diversity index } & \multirow{2}{*}{$\begin{array}{l}\text { Turnover } \\
\text { Bray-Curtis dissimilarity distance }\end{array}$} \\
\hline & Alpha & Beta & Gamma & \\
\hline \multicolumn{5}{|l|}{ Woody plant species } \\
\hline Farmland & 2.36 & 10.89 & 25.65 & 0.65 \\
\hline Forest with coffee management & 3.96 & 2.12 & 8.39 & 0.39 \\
\hline Forest without coffee management & 8.51 & 4.32 & 36.80 & 0.58 \\
\hline \multicolumn{5}{|l|}{ Ecosystem services } \\
\hline Farmland & 5.33 & 1.75 & 9.34 & 0.47 \\
\hline Forest with coffee management & 8.02 & 1.18 & 9.48 & 0.25 \\
\hline Forest without coffee management & 7.94 & 1.27 & 10.10 & 0.31 \\
\hline
\end{tabular}

Note that differences in gamma diversity especially may at least partly be driven by the lower sample sizes in forest with coffee management (farmland $n=72$, forest without coffee management $n=63$, forest with coffee management $n=43$ )

\section{Discussion}

Local people, particularly in developing countries, manage landscapes to harbour a diversity of plant species and associated ES, from which they benefit both materially and immaterially (Shackleton et al. 2007; Sunderland 2011; Manning et al. 2018). Revealing the effect of biodiversity on specific benefits derived in smallholder-dominated landscapes, however, has remained a challenge. Here, we examined the association between woody plant diversity and ES that provide key benefits to local people in a rural landscape of southwestern Ethiopia. We documented the potential supply of multiple ES in all major landuse types across the landscapes, and found a positive relationship between woody plant species diversity and ES diversity.

With respect to our first hypothesis-i.e. that different land-use types would provide diverse ES and that ES composition would vary among land-use 


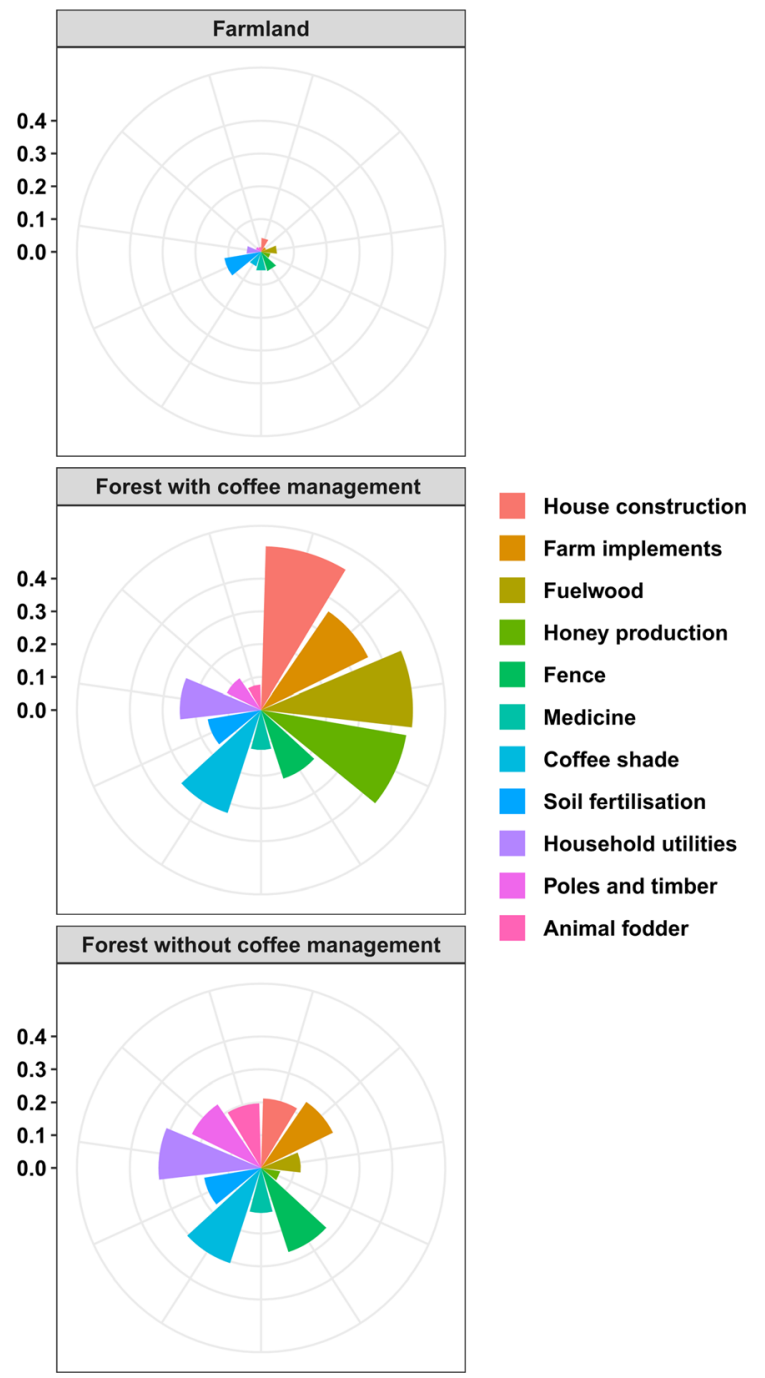

Fig. 3 Type and mean total ES supply provided by each landuse type. Note that each ES was determined based on people's actual use of woody plant species and their presence in each land-use type in the study area

types-we found that all three focal land-use types added to ES-based landscape multifunctionality delivered by woody plants in different ways. We found that woody plants in farmland can contribute to landscape ES multifunctionality by providing above-average levels of soil fertilisation and medicine. Farmland can also provide other services in different parts of the landscape, as indicated by relatively high levels of ES beta diversity and turnover. We found that forests, in contrast, can contribute to landscape ES multifunctionality in that they provide high ES supply (i.e. high alpha and gamma diversities), but with a relatively uniform distribution across the landscape (i.e. low beta diversity and turnover). Forests were primary sources in the landscape for fuelwood, construction materials and honey (forest with coffee management) and for animal fodder, household utilities and poles and timber (forest without coffee management). Our findings suggest that the landscape in its entirety maintains different aspects of woody plant and ES diversities, with particularly targeted management occurring in the farmland (Forman 1990; Wu 2013). In line with this, the empirical findings by Jiren et al. (2017) in our study area showed that many local people favoured multifunctionality-oriented land management. Such integrated land management may be rooted in historical land use, as indicated by a higher woody plant species richness in long-established compared to more recently converted farmland (Shumi et al. 2018).

The current supply of multiple ES in southwestern Ethiopian landscapes contrasts with modern, intensified agricultural landscapes, such as those illustrated by Foley et al. (2005), which are typically managed for maximizing the provisioning of few services. In contrast, multifunctional land use, as it is currently practiced in our study area, has clear parallels with recent recommendations for integrated landscape management (i.e. where the landscape is managed to simultaneously support biodiversity conservation and the provisioning of multiple ES) (Kremen and Merenlender 2018), and mirrors patterns of ES multifunctionality in European cultural landscapes such as in Central Romania (Hanspach et al. 2014). In our study, ES multifunctionality not only differed between sites but also between different land-use types. Our finding that mean levels of key potential ES provided by woody plants were higher in forests than in farmland is likely to be because of higher woody plant species richness and abundance in forests. This is consistent with other studies (e.g. Gamfeldt et al. 2013; Brockerhoff et al. 2017) that showed a high quantity of ES in forests, driven by high tree species richness and abundance.

Consistent with our second hypothesis-i.e. that ES diversity would be positively related to woody plant species diversity-our findings confirmed a positive relationship between these two variables in all three land-use types. Our empirical findings agree with models (e.g. Peterson et al. 1998; Cardinale et al. 2011) and experimental studies (e.g. Tilman et al. 


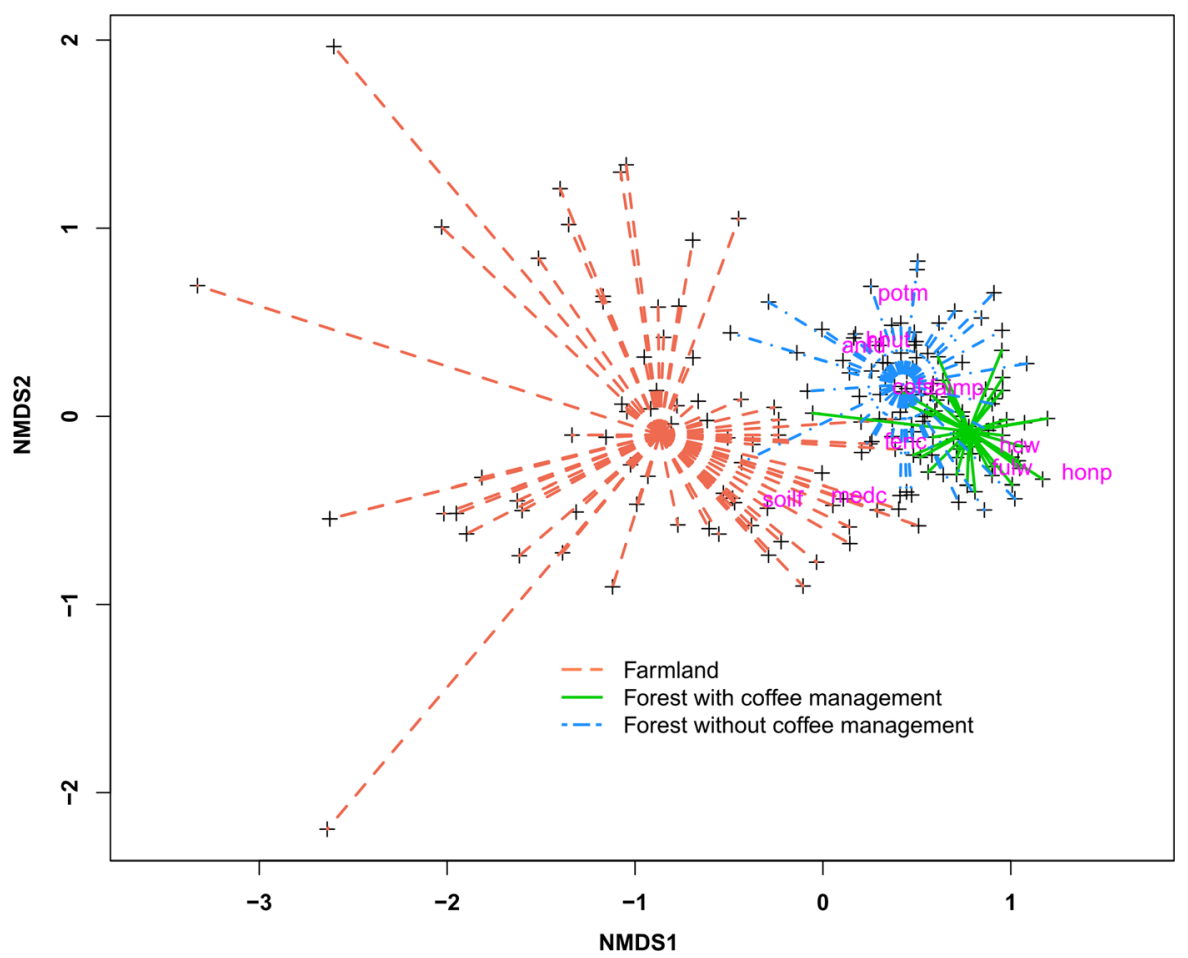

Fig. 4 Non-metric multidimensional scaling (NMDS, twodimensional, stress $=0.114$ ) ordination of all 181 studied plots (indicated by "+" sign) and ES (indicated by their short name). Study plots were grouped by land-use type and connected to their centroids by lines: plots in farmland (coral lines), plots in forest with coffee management (green lines) and plots forest

2006; Letourneau et al. 2011; Liang et al. 2016) that illustrate positive biodiversity-ES diversity relationships. In our study area, the initial increase in ES diversity with species diversity was steeper in farmland than in forests. At higher levels of woody plant species richness and diversity, farmland sites had similar levels of ES diversity compared to forests, illustrating that maintaining woody plant species diversity in farmland can be useful for the provision of multiple ES in addition to agricultural production, as also noted elsewhere (e.g. Isbell et al. 2017). Maintaining highly diversified agroecosystems could be important for ecosystem resilience and therefore the sustainable supply of multiple ES (e.g. Isbell et al. $2015,2017)$. This may be of particular importance in places that have a relatively high likelihood of facing environmental stressors, such as our study area and other smallholder systems in the tropics, including exposure to extended droughts or severe weather without coffee management (blue lines). ES (magenta text) include: hcw = house construction; faimp = farm implements; fulw $=$ fuelwood; honp $=$ honey production; fenc $=$ fence; medc $=$ medicine $;$ cofs $=$ coffee shade $;$ soilf $=$ soil fertilisa tion; hhut = household utilities; potm = poles and timber; and anfd = animal fodder ES

events (Bergengren et al. 2011; Moat et al. 2017; Sintayehu 2018).

At sites with low species richness, however, sitelevel ES diversity in farmland was low, suggesting that farmland might be locally managed for a more narrow, targeted range of ES, which is in line with the current agricultural land-use policies-that is, an agricultural intensification that reduces or eliminates woody plant species (Kassa et al. 2016). This pattern parallels findings by other authors, where intensified farming, as compared to diversified agroecosystems richer in woody plant species, reduced ES supply (RaudseppHearne et al. 2010a; Kremen and Miles 2012; Allan et al. 2015). However, at the landscape level, farmland had high beta diversities of species and ES, suggesting that despite targeted management at the site level, the landscape as a whole remains to be managed for species diversity and ES multifunctionality.

The possible degradation of ES or loss of biodiversity does not always necessarily result in reduced 
Table 3 Results of the linear mixed effect models testing the relationship between ES Shannon diversity in response (a) to woody plant species richness and (b) woody plant species Shannon diversity

\begin{tabular}{|c|c|c|c|c|}
\hline Response & Term & Coefficient & $\begin{array}{l}\text { Standard } \\
\text { error }\end{array}$ & $\mathrm{P}$-value \\
\hline \multirow{6}{*}{$\begin{array}{l}\text { (a) ES Shannon diversity to species } \\
\text { richness }\end{array}$} & Intercept & 1.231 & 0.060 & $<0.001 * * *$ \\
\hline & Forest with coffee management & 0.501 & 0.201 & $0.014 *$ \\
\hline & Forest without coffee management & 0.181 & 0.296 & 0.542 \\
\hline & Species richness & 0.363 & 0.039 & $<0.001 * * *$ \\
\hline & $\begin{array}{l}\text { Forest with coffee management: species } \\
\text { richness }\end{array}$ & -0.225 & 0.080 & $0.006 * *$ \\
\hline & $\begin{array}{l}\text { Forest without coffee management: species } \\
\text { richness }\end{array}$ & -0.133 & 0.105 & 0.208 \\
\hline \multirow{6}{*}{$\begin{array}{l}\text { (b) ES Shannon diversity to species } \\
\text { Shannon diversity }\end{array}$} & Intercept & 1.305 & 0.060 & $<0.001 * * *$ \\
\hline & Forest with coffee management & 0.542 & 0.109 & $<0.001 * * *$ \\
\hline & Forest without coffee management & 0.439 & 0.180 & $0.015^{*}$ \\
\hline & Species Shannon diversity & 0.414 & 0.050 & $<0.001 * * *$ \\
\hline & $\begin{array}{l}\text { Forest with coffee management: species } \\
\text { Shannon diversity }\end{array}$ & -0.231 & 0.080 & $0.005^{* *}$ \\
\hline & $\begin{array}{l}\text { Forest without coffee management: species } \\
\text { Shannon diversity }\end{array}$ & -0.225 & 0.091 & $0.006 * *$ \\
\hline
\end{tabular}

Predictor terms are continuous except for land-use types. The coefficient for land-use type indicates the difference between farmland, forest with coffee management, and forest without coffee management, with farmland being the reference level

Significance levels are indicated by: * where $\mathrm{P}<0.05$, ** where $\mathrm{P}<0.01$, *** where $\mathrm{P}<0.001$

human-well-being (Rodríguez et al. 2006; RaudseppHearne et al. 2010b; Daw et al. 2016). Some people may increase their efficiency or the extent to which they appropriate ES, or replace direct ES supply from other sources or with market purchases (Daw et al. 2011, 2016; Pritchard et al. 2018). However, not all people may be able to compensate ES degradation equally. Especially for already marginalized smallholder farmers, a continued loss of woody plant species and ES diversity is likely to impact livelihoods negatively. Losing woody plant species reduces the landscape-level supply of material for heating and cooking, house construction and medicine, and corresponds to a general decline in cultural and regulating services (Raudsepp-Hearne et al. 2010a; Allan et al. 2015; Reed et al. 2017). Those already marginalized often have limited physical access to alternative sources of these materials elsewhere in the landscape (e.g. Dorresteijn et al. 2017) and may be unable to purchase them due to financial limitations (Daw et al. 2011; Pritchard et al. 2018; Reyers et al. 2018). And while biodiversity and ES loss thus directly affects especially poor people's livelihoods, the effects are likely to ripple further and result in a more fundamental loss of choices, hopes, culture, health, social relations and natural insurances (MA 2005).

Compared to farmland, ES diversity increased less steeply in forests with additional woody plant species being present, which-together with the already highlighted lower beta diversity and turnover in forests-suggests a high level of functional redundancy in forests. Such redundancy indicates that the functional consequences that are related to a loss of woody plant species may (at least partly) be mitigated by other species; conversely, the addition of more woody plant species to the already diverse forest system may contribute only little to increase ES multifunctionality. Such redundancy of species in highly species-rich systems has been noted in models and experimental studies (e.g. Peterson et al. 1998; Naeem et al. 2002; Cardinale et al. 2012). Maintaining functional redundancy can be valuable to enhance system resilience to multiple drivers of environmental change (Naeem and Li 1997; Yachi and Loreau 1999; Ives et al. 2000; Loreau et al. 2003), including climate 
Fig. 5 Relationship between a woody plant species richness and ES Shannon diversity, and b species Shannon diversity and ES Shannon diversity, in farmland (red line and box), forest with coffee management (green line and box), and forest without coffee management (blue line and box). Regression lines represent the predicted ES Shannon diversity and shaded areas their $95 \%$ confidence intervals for each land use. Note that the $\mathrm{X}$-axes display backtransformed values of species richness
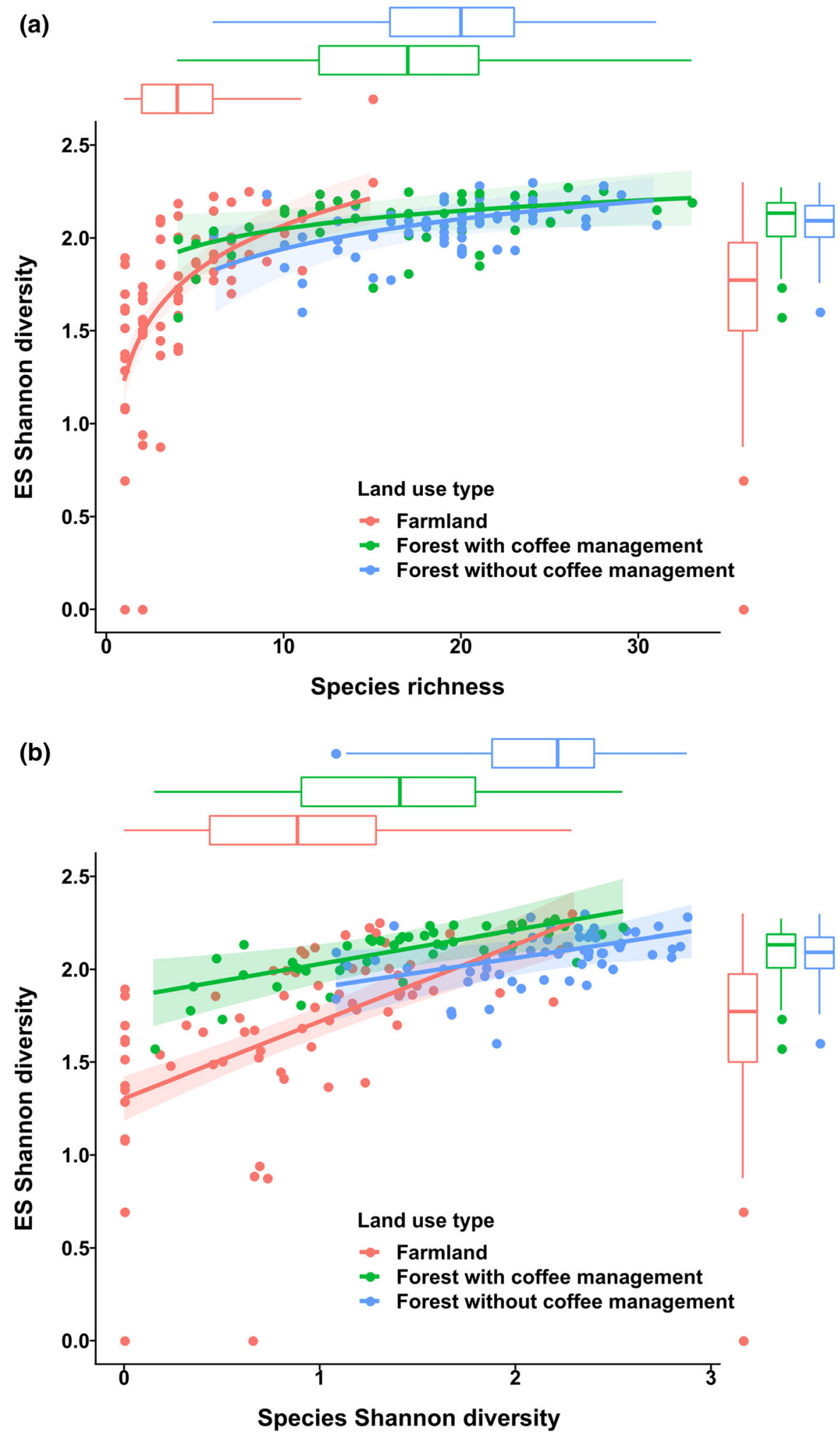
change (e.g. Isbell et al. 2015, 2017; Hisano et al. 2018).

Implications for sustainability

Currently, there is growing pressure to commodify landscapes, including via controversial methods of "sustainable intensification" (e.g. Tilman et al. 2011; Mueller et al. 2012; Godfray and Garnett 2014). However, optimizing landscapes for efficient crop production can inadvertently degrade landscape multifunctionality and biodiversity (e.g. RaudseppHearne et al. 2010a; Rasmussen et al. 2018), leading to unfavourable consequences for the environment and local livelihoods (Tscharntke et al. 2012; Loos et al. 2014).

In contrast to widespread calls for intensification, which typically focuses on a few crops only (e.g. Godfray and Garnett 2014), our study underlines the possible benefits of landscape multifunctionality for both people and biodiversity. Multifunctional smallholder landscapes can harbour high biodiversity and provide diverse ES, at both local and landscape scales. Such diversity not only generates immediate material benefits, but also underpins important regulating services (Raudsepp-Hearne et al. 2010a), which in turn, underpin resilience to environmental changes (Rockström et al. 2009; Isbell et al. 2017; Hisano et al. 2018).

Our findings are also relevant in the context of the United Nations Sustainable Development Goals (SDGs; UN 2015). Instead of aggravating competing land uses and trade-offs between different ES (de Groot et al. 2010; DeClerck et al. 2016; Rasmussen et al. 2018), a shift from production-oriented agriculture towards people- and biodiversity-centred agriculture could uncover numerous new synergies between production, conservation and human wellbeing (DeClerck et al. 2016; Kremen and Merenlender 2018). Integrated landscape management can, for instance, improve ES levels such as in the provision of food (SDG1, SDG2 and SDG3), the regulation of water (SDG6 and SDG9), fuel supply (SDG7) and carbon sequestration (SDG13), as well as providing habitat for a diversity of species (SDG14 and SDG15) (UN 2015; DeClerck 2016; Singh et al. 2018).

Managing landscapes for multifunctionality on its own, however, seems insufficient for sustainability. Without further improvements in the equity of land access, tenure security, and participation in decisionmaking, already marginalized people will continue to lack access to important ES (Daw et al. 2011; Leta et al. 2019). Redressing existing problems requires recognition and improved understanding of people's livelihoods (e.g. Jiren et al. 2017; Leta et al. 2019; Shumi et al. 2019a), as well as more clearly defined property rights and better access to land and other environmental resources (Lemenih and Kassa 2014; Tura 2018; Shumi et al. 2019a). Both ecological and social aspects in the landscape thus must be carefully managed to prevent a worsening of the livelihood situation and wellbeing of people, especially those who are already marginalized.

\section{Conclusion}

Ensuring biodiversity conservation while also improving human wellbeing is a prominent challenge in many developing countries. Here, by combining data on woody plant species and ES that people depend upon, we demonstrated different aspects of landscape multifunctionality and positive ES diversity-biodiversity relationships in southwestern Ethiopia. Our study showed multifunctionality of both farmland and forests, as well as a link between woody plant species diversity and ES diversity across the landscape. Landscape multifunctionality thus appeared to successfully contribute to multiple sustainable development goals, benefiting both people and biodiversity. Based on our findings we recommend to (1) promote landscape multifunctionality by drawing on the positive relationship between biodiversity and ES diversity; (2) strengthen existing conservation policies to encompass the entire landscape mosaic and thereby increase the complementary functions of different land-use types for biodiversity conservation and ES provisioning; and (3) conduct further social-ecological studies that use mixed data to elicit socially relevant relationships between biodiversity and ES diversity.

Acknowledgements The study was funded through a European Research Council (ERC) Consolidator Grant (FP7IDEAS-ERC, Project ID 614278) to J. Fischer (SESyP). We thank the Governments of Ethiopia and Oromia Regional State for their permission to conduct the research. We also thank the staff of the different woreda and kebele offices and the local farmers for their cooperation. We thank field assistants and 
drivers for their support. The paper was substantially improved through the constructive feedback by two anonymous reviewers.

Open Access This article is licensed under a Creative Commons Attribution 4.0 International License, which permits use, sharing, adaptation, distribution and reproduction in any medium or format, as long as you give appropriate credit to the original author(s) and the source, provide a link to the Creative Commons licence, and indicate if changes were made. The images or other third party material in this article are included in the article's Creative Commons licence, unless indicated otherwise in a credit line to the material. If material is not included in the article's Creative Commons licence and your intended use is not permitted by statutory regulation or exceeds the permitted use, you will need to obtain permission directly from the copyright holder. To view a copy of this licence, visit http://creativecommons.org/licenses/by/4.0/.

Funding Open Access funding enabled and organized by Projekt DEAL.

\section{References}

Ahammad R, Stacey N, Sunderland TCH (2019) Use and perceived importance of forest ecosystem services in rural livelihoods of Chittagong Hill Tracts, Bangladesh. Ecosyst Serv 35:87-98

Allan E, Manning P, Alt F, Binkenstein J, Blaser S, Blüthgen N, Böhm S, Grassein F, Hölzel N, Klaus VH, Kleinebecker T, Morris EK, Oelmann Y, Prati D, Renner SC, Rillig MC, Schaefer M, Schloter M, Schmitt B, Schöning I, Schrumpf M, Solly E, Sorkau E, Steckel J, Steffen-Dewenter I, Stempfhuber B, Tschapka M, Weiner CN, Weisser WW, Werner M, Westphal C, Wilcke W, Fischer M (2015) Land use intensification alters ecosystem multifunctionality via loss of biodiversity and changes to functional composition. Ecol Lett 18:834-843

Ango TG (2016) Ecosystem services and disservices in an agriculture-forest mosaic: a study of forest and tree management and landscape transformation in southwestern Ethiopia. Dissertation, Stockholm University, Stockholm

Ango TG, Börjeson L, Senbeta F, Hylander K (2014) Balancing ecosystem services and disservices: smallholder farmers' use and management of forest and trees in an agricultural landscape in southwestern Ethiopia. Ecol Soc 19(1):30

Anthony F, Combes MC, Astorga C, Bertrand B, Graziosi G, Lashermes P (2002) The origin of cultivated Coffea arabica L. varieties revealed by AFLP and SSR markers. Theor Appl Genet 104:894-900

Balvanera P, Siddique I, Dee L, Paquette A, Isbell F, Gonzalez A, Byrnes J, O’Connor MI, Hungate BA, Griffin JN (2014) Linking biodiversity and ecosystem services: current uncertainties and the necessary next steps. Bioscience 64:49-57

Baselga A, Orme D, Villeger S, De Bortoli J, Leprieur F (2018) betapart: Partitioning beta diversity into turnover and nestedness components. R package version 1.5.1. https:// CRAN.R-project.org/package=betapart

Bergengren JC, Waliser DE, Yung YL (2011) Ecological sensitivity: a biospheric view of climate change. Clim Change 107:433-457

Berkes F, Colding J, Folke C (2003) Navigating social-ecological systems: building resilience for complexity and change. Cambridge University Press, Cambridge, New York. https://doi.org/10.1016/j.biocon.2004.01.010

Brockerhoff EG, Barbaro L, Castagneyrol B, Forrester DI, Gardiner B, González-Olabarria JR, Lyver POB, Meurisse N, Oxbrough A, Taki H, Thompson ID, van der Plas F, Jactel H (2017) Forest biodiversity, ecosystem functioning and the provision of ecosystem services. Biodivers Conserv 26:3005-3035

Burkhard B, Kroll F, Nedkov S, Müller F (2012) Mapping ecosystem service supply, demand and budgets. Ecol Indic 21:17-29

Cardinale BJ, Matulich KL, Hooper DU, Byrnes JE, Duffy E, Gamfeldt L, Balvanera P, O'Connor MI, Gonzalez A (2011) The functional role of producer diversity in ecosystems. Am J Bot 98:572-592

Cardinale BJ, Duffy JE, Gonzalez A, Hooper DU, Perrings C, Venail P, Narwani A, Mace GM, Tilman D, Wardle DA, Kinzig AP, Daily GC, Loreau M, Grace JB, Larigauderie A, Srivastava DS, Naeem S (2012) Biodiversity loss and its impact on humanity. Nature 486:59-67

Cheng S, Hiwatashi Y, Imai H, Naito M, Numata T (1998) Deforestation and degradation of natural resources in Ethiopia: forest management implications from a case study in the Belete-Gera forest. J For Res 3:199-204

Crewett W, Bogale A, Korf B (2008) Land tenure in Ethiopia: continuity and change, shifting rulers, and the quest for state control. CAPRi Working Paper 91. International Food Policy Research Institute: Washington, DC. https://doi.org/ 10.2499/CAPRiWP91

Daw T, Brown K, Rosendo S, Pomeroy R (2011) Applying the ecosystem services concept to poverty alleviation: the need to disaggregate human well-being. Environ Conserv 38:370-379

Daw TM, Hicks CC, Brown K et al (2016) Elasticity in ecosystem services: exploring the variable relationship between ecosystems and human well-being. Ecol Soc 21(2): 11

de Groot RS, Alkemade R, Braat L, Hein L, Willemen L (2010) Challenges in integrating the concept of ecosystem services and values in landscape planning, management and decision making. Ecol Complex 7:260-272

DeClerck F (2016) Biodiversity central to food security. Nature 531:305

DeClerck FAJ, Jones SK, Attwood S, Bossio D, Girvetz E, Chaplin-Kramer B, Enfors E, Fremier AK, Gordon LJ, Kizito F, Noriega IL, Matthews N, McCartney M, Meacham M, Noble A, Quintero M, Remans R, Soppe R, Willemen L, Wood SLR, Zhang W (2016) Agricultural ecosystems and their services: the vanguard of sustainability? Curr Opin Environ Sustain 23:92-99

Díaz S, Fargione J, Chapin FS, Tilman D (2006) Biodiversity loss threatens human well-being. PLoS Biol 4:e277

Díaz S, Demissew S, Carabias J, Joly C, Lonsdale M, Ash N, Larigauderie A, Adhikari JR, Arico S, Báldi A, Bartuska A, 
Baste IA, Bilgin A, Brondizio E, Chan KMA, Figueroa VE, Duraiappah A, Fischer M, Hill R, Koetz T, Leadley P, Lyver P, Mace GM, Martin-Lopez B, Okumura M, Pacheco D, Pascual U, Pérez ES, Reyers B, Roth E, Saito O, Scholes RJ, Sharma N, Tallis H, Thaman R, Watson R, Yahara T, Hamid ZA, Akosim C, Al-Hafedh Y, Allahverdiyev A, Amankwah E, Asah ST, Asfaw A, Bartus G, Brooks LA, Caillaux J, Dalle G, Darnaedi D, Driver A, Erpul G, Escobar-Eyzaguirre P, Failler P, Fouda AMM, Fu B, Gundimeda H, Hashimoto S, Homer F, Lavorel S, Lichtenstein G, Mala WA, Mandivenyi W, Matczak P, Mbizvo C, Mehrdadi M, Metzger JP, Mikissa JB, Moller H, Mooney HA, Mumby P, Nagendra H, Nesshover C, OtengYeboah AA, Pataki G, Roué M, Rubis J, Schultz M, Smith P, Sumaila R, Takeuchi K, Thomas S, Verma M, YeoChang Y, Zlatanova D (2015) The IPBES conceptual framework-connecting nature and people. Curr Opin Environ Sustain 14:1-16

Díaz S, Pascual U, Stenseke M, Martín-López B, Watson RT, Molnár Z, Hill R, Chan KMA, Baste IA, Brauman KA, Polasky S, Church A, Lonsdale M, Larigauderie A, Leadley PW, van Oudenhoven APE, van der Plaat F, Schröter M, Lavorel S, Aumeeruddy-Thomas Y, Bukvareva E, Davies K, Demissew S, Erpul G, Failler P, Guerra CA, Hewitt CL, Keune H, Lindley S, Shirayama Y (2018) Assessing nature's contributions to people. Science 359:270-272

Dorresteijn I, Schultner J, Collier NF, Hylander K, Senbeta F, Fischer J (2017) Disaggregating ecosystem services and disservices in the cultural landscapes of southwestern Ethiopia: a study of rural perceptions. Landsc Ecol 32:2151-2165

Eigenbrod F (2016) Redefining landscape structure for ecosystem services. Curr Landsc Ecol Rep 1:80-86

Fagerholm N, Käyhkö N, Ndumbaro F, Khamis M (2012) Community stakeholders' knowledge in landscape assessments-mapping indicators for landscape services. Ecol Indic 18:421-433

FAO (2014) State of the world's forests—enhancing the socioeconomic benefits from forests. FAO, Rome

FDRE (1995) Constitution of the federal democratic republic of Ethiopia

Fischer J, Hartel T, Kuemmerle T (2012) Conservation policy in traditional farming landscapes. Conserv Lett 5:167-175

Flora of Ethiopia and Eritrea (1989-2006) Flora of Ethiopia and Eritrea. Addis Ababa: The National Herbarium and Uppsala, Sweden: The Department of Systematic Botany, Uppsala University

Foley JA, DeFries R, Asner GP (2005) Global consequences of land use. Science 309:570-574

Folke C (2006) Resilience: the emergence of a perspective for social-ecological systems analyses. Glob Environ Change 16:253-267

Folke C, Carpenter S, Walker B, Scheffer M, Elmqvist T, Gunderson L, Holling CS (2004) Regime shifts, resilience, and biodiversity in ecosystem management. Annu Rev Ecol Evol Syst 35:557-581

Forman RTT (1990) Ecologically sustainable landscapes: the role of spatial configuration. In: Zonneveld IS, Forman RTT (eds) Changing landscapes: an ecological perspective. Springer, New York, pp 261-278
Friis I, Demissew S, van Breugel P (2010) Atlas of the potential vegetation of Ethiopia. Royal Danish Academy of Science and Letters, Copenhagen

Gamfeldt L, Hillebrand H, Jonsson PR (2008) Multiple functions increase the importance of biodiversity for overall ecosystem functioning. Ecology 89:1223-1231

Gamfeldt L, Snäll T, Bagchi R, Jonsson M, Gustafsson L, Kjellander P, Ruiz-Jaen MC, Fröberg M, Stendahl J, Philipson CD, Mikusiński G, Andersson E, Westerlund B, Andrén H, Moberg F, Moen J, Bengtsson J (2013) Higher levels of multiple ecosystem services are found in forests with more tree species. Nat Commun 4:1340

Godfray CHJ, Garnett T (2014) Food security and sustainable intensification. Philos Trans R Soc 369:20120273

Hanspach J, Hartel T, Milcu AI, Mikulcak F, Dorresteijn I, Loos J, von Wehrden H, Kuemmerle T, Abson DJ, KovácsHostyánszki A, Báldi A, Fischer J (2014) A holistic approach to studying social-ecological systems and its application to Southern Transylvania. Ecol Soc. https://doi. org/10.5751/ES-06915-190432

Hartel T, Dorresteijn I, Klein C, Máthé O, Moga CI, Öllerer K, Roellig M, von Wehrden H, Fischer J (2013) Wood-pastures in a traditional rural region of Eastern Europe: characteristics, management and status. Biol Conserv 166:267-275

Hector A, Bagchi R (2007) Biodiversity and ecosystem multifunctionality. Nature 448:188-190

Hisano M, Searle EB, Chen HYH (2018) Biodiversity as a solution to mitigate climate change impacts on the functioning of forest ecosystems. Biol Rev 93:439-456

Isbell F, Calcagno V, Hector A, Connolly J, Harpole WS, Reich PB, Scherer-Lorenzen M, Schmid B, Tilman D, van Ruijven J, Weigelt A, Wilsey BJ, Zavaleta ES, Loreau M (2011) High plant diversity is needed to maintain ecosystem services. Nature 477:199-202

Isbell F, Craven D, Connolly J, Loreau M, Schmid B (2015) Biodiversity increases the resistance of ecosystem productivity to climate extremes. https://doi.org/10.1038/ nature 15374

Isbell F, Adler PR, Eisenhauer N, Fornara D, Kimmel K, Kremen C, Letourneau DK, Liebman M, Polley HW, Quijas S, Scherer-Lorenzen M (2017) Benefits of increasing plant diversity in sustainable agroecosystems. J Ecol 105:871-879

Ives AR, Klug JL, Gross K (2000) Stability in complex communities. Ecol Lett 3:399-411

Jara T, Hylander K, Nemomissa S (2017) Tree diversity across different tropical agricultural land use types. Agric Ecosyst Environ 240:92-100

Jiren TS, Dorresteijn I, Schultner J, Fischer J (2017) The governance of land use strategies: institutional and social dimensions of land sparing and land sharing. Conserv Lett. https://doi.org/10.1111/conl.12429

Jönsson M, Snäll T (2020) Ecosystem service multifunctionality of low-productivity forests and implications for conservation and management. J Appl Ecol 57:695-706

Kassa H, Dondeyne S, Poesen J, Frankl A, Nyssen J (2016) Transition from forest- to cereal-based agricultural systems: a review of the drivers of land-use change and degradation in southwest Ethiopia. Land Degrad Dev 28:431-449 
Kremen C, Miles A (2012) Ecosystem services in biologically diversified versus conventional farming systems: benefits, externalities, and trade-offs. Ecol Soc 17(4):40

Kremen C, Merenlender AM (2018) Landscapes that work for biodiversity and people. Science 362 :eaau6020

Lande R (1996) Statistics and partitioning of species diversity, and similarity among multiple communities. Oikos 76:5-13

Lefcheck JS, Byrnes JEK, Isbell F, Gamfeldt L, Griffin JN, Eisenhauer N, Hensel MJS, Hector A, Cardinale BJ, Duffy JE (2015) Biodiversity enhances ecosystem multifunctionality across trophic levels and habitats. Nat Commun 6:1-7

Lemenih M, Kassa H (2014) Re-greening Ethiopia: history, challenges and lessons. Forests 5:1896-1909

Leta G, Kelboro G, Van Assche K, Stellmacher T, Hornidge AK (2019) Rhetorics and realities of participation: the Ethiopian agricultural extension system and its participatory turns. Crit Policy Stud 00:1-20

Letourneau DK, Armbrecht I, Rivera BS, Lerma JM, Carmona EJ, Daza MC, Escobar S, Galindo V, Gutiérrez C, López SD, Mejía JL, Rangel AMA, Rangel JH, Rivera L, Saavedra CA, Torres AM, Trujillo AR (2011) Does plant diversity benefit agroecosystems? A synthetic review. Ecol Appl 21:9-21

Liang J, Crowther TW, Picard N, Wiser S, Zhou M, Alberti G, Schulze ED, McGuire AD, Bozzato F, Pretzsch H, deMiguel S, Paquette A, Hérault B, Scherer-Lorenzen M, Barrett CB, Glick HB, Hengeveld GM, Nabuurs GJ, Pfautsch S, Viana H, Vibrans AC, Ammer C, Schall P, Verbyla D, Tchebakova N, Fischer M, Watson JV, Chen HYH, Lei X, Schelhaas MJ, Lu H, Gianelle D, Parfenova EI, Salas C, Lee E, Lee B, Kim HS, Bruelheide H, Coomes DA, Piotto D, Sunderland T, Schmid B, Gourlet-Fleury S, Sonké B, Tavani R, Zhu J, Brandl S, Vayreda J, Kitahara F, Searle EB, Neldner VJ, Ngugi MR, Baraloto C, Frizzera L, Bałazy R, Oleksyn J, Zawiła-Niedźwiecki T, Bouriaud O, Bussotti F, Finér L, Jaroszewicz B, Jucker T, Valladares F, Jagodzinski AM, Peri PL, Gonmadje C, Marthy W, O'Brien T, Martin EH, Marshall AR, Rovero F, Bitariho R, Niklaus PA, Alvarez-Loayza P, Chamuya N, Valencia R, Mortier F, Wortel V, Engone-Obiang NL, Ferreira LV, Odeke DE, Vasquez RM, Lewis SL, Reich PB (2016) Positive biodiversity-productivity relationship predominant in global forests. Science 354:8957

Loreau M, Mouquet N, Gonzalez A (2003) Biodiversity as spatial insurance in heterogeneous landscapes. Proc Natl Acad Sci 100:12765-12770

Loos J, Abson DJ, Chappell MJ, Hanspach J, Mikulcak F, Tichit M, Fischer J (2014) Putting meaning back into "sustainable intensification." Front Ecol Environ 12:356-361

MA (2003) Ecosystems and human well-being: a framework for assessment. Millennium ecosystem assessment. Island Press, Washington, DC

MA (2005) Ecosystems and human well-being: biodiversity synthesis. Millennium ecosystem assessment. World Resources Institute, Washington, DC

Maestre FT, Quero JL, Gotelli NJ, Escudero A, Ochoa V, Delgado-Baquerizo M, García-Gómez M, Bowker MA, Soliveres $\mathrm{S}$, Escolar $\mathrm{C}$, García-Palacios $\mathrm{P}$, Berdugo $\mathrm{M}$, Valencia E, Gozalo B, Gallardo A, Aguilera L, Arredondo
T, Blones J, Boeken B, Bran D, Conceição AA, Cabrera O, Chaieb M, Derak M, Eldridge DJ, Espinosa CI, Florentino A, Gaitán J, Gatica MG, Ghiloufi W, Gómez-González S, Gutiérrez JR, Hernández RM, Huang X, Huber-Sannwald E, Jankju M, Miriti M, Monerris J, Mau RL, Morici E, Naseri K, Ospina A, Polo V, Prina A, Pucheta E, RamírezCollantes DA, Romão R, Tighe M, Torres-Díaz C, Val J, Veiga JP, Wang D, Zaady E (2012) Plant species richness and ecosystem multifunctionality in global drylands. Science 335:214-218

Manning P, van der Plas F, Soliveres S, Allan E, Maestre FT, Mace G, Whittingham MJ, Fischer M (2018) Redefining ecosystem multifunctionality. Nat Ecol Evol 2:427-436

Mitchell MGE, Suarez-Castro AF, Martinez-Harms M, Maron M, McAlpine C, Gaston KJ, Johansen K, Rhodes JR (2015) Reframing landscape fragmentation's effects on ecosystem services. Trends Ecol Evol 30:190-198

Mittermeier RA, Turner WR, Larsen FW, Brooks TM, Gascon C (2011) Global biodiversity conservation: the critical role of hotspots. In: Zachos FE, Habel JC (eds) Biodiversity hotspots: distribution and protection of conservation priority areas. Springer, Berlin Heidelberg

Moat J, Williams J, Baena S, Wilkinson T, Gole TW, Challa ZK, Demissew S, Davis AP (2017) Resilience potential of the Ethiopian coffee sector under climate change. Nat Plants. https://doi.org/10.1038/nplants.2017.81

Mueller ND, Gerber JS, Johnston M, Ray DK, Ramankutty N, Foley JA (2012) Closing yield gaps through nutrient and water management. Nature 490:254-257

Naeem S, Li S (1997) Biodiversityenhances ecosystem reliability. Nature 390:507-509

Naeem S, Loreau M, Inchausti P (2002) Biodiversity and ecosystem functioning: the emergence of a synthetic ecological framework. In: Loreau M, Naeem S, Inchausti P (eds) Biodiversity and ecosystem functioning. Oxford University Press, Oxford, pp 3-11

Neyret M, Fischer M, Allan E, Hölzel N, Klaus VH, Kleinebecker T, Krauss J, Le Provost G, Peter S, Schenk N, Simons NK, van der Plas F, Binkenstein J, Börshig C, Jung K, Prati D, Schäfer M, Schäfer D, Schöning I, Schrumpf M, Tschapka M, Westphal C, Manning P (2020) Landscape management for grassland multifunctionality. BioRxiv. https://doi.org/10.1101/2020.07.17.208199

O'Farrell PJ, Anderson PML (2010) Sustainable multifunctional landscapes: a review to implementation. Curr Opin Environ Sustain 2:59-65

Oksanen J, Blanchet FG, Friendly M, Kindt R, Legendre P, McGlinn D, Minchin PR, O'Hara RB, Simpson GL, Solymos P, Stevens MHH, Szoecs E, Wagner H (2019) vegan: community ecology package. $\mathrm{R}$ package version 2.5-2. https://CRAN.R-project.org/package=vegan

Perfecto I, Vandermeer J (2010) The agroecological matrix as alternative to the land-sparing/agriculture intensification model. Proc Natl Acad Sci 107:5786-5791

Perfecto I, Armbrecht I, Philpott SM, Soto-Pinto L, Dietsch TV (2007) Shaded coffee and the stability of rainforest margins in northern Latin America. In: Tscharntke T, Leuschner C, Zeller M, Guhardja E, Bidin A (eds) The stability of tropical rainforest margins, linking ecological, economic and social constraints of land use and conservation. Springer, Berlin, pp 227-263 
Peterson G, Allen CR, Holling CS (1998) Ecological resilience, biodiversity, and scale. Ecosystems 1:6-18

Plieninger T, Dijks S, Oteros-Rozas E, Bieling C (2013) Assessing, mapping, and quantifying cultural ecosystem services at community level. Land Use Policy 33:118-129

Pritchard R, Ryan CM, Grundy I, van der Horst D (2018) Human appropriation of net primary productivity and rural livelihoods: findings from six villages in Zimbabwe. Ecol Econ 146:115-124

R core Team (2019) R: a language and environment for statistical computing. R foundation for Statistical Computing, Vienna, Austria. http://www.R.project.org/

Rahman SA, Foli S, Al Pavel MA, Al Mamun MA, Sunderland $\mathrm{T}$ (2015) Forest, trees and agroforestry: better livelihoods and ecosystem services from multifunctional landscapes. Int J Dev Sustain 4:479-491

Ramankutty N, Evan AT, Monfreda C, Foley JA (2008) Farming the planet: 1 . Geographic distribution of global agricultural lands in the year 2000. Glob Biogeochem Cycles 22:1-19

Rasmussen LV, Watkins C, Agrawal A (2017) Forest contributions to livelihoods in changing agriculture-forest landscapes. For Policy Econ 84:1-8

Rasmussen LV, Coolsaet B, Martin A, Mertz O, Pascual U, Corbera E, Dawson N, Fisher JA, Franks P, Ryan CM (2018) Social-ecological outcomes of agricultural intensification. Nat Sustain 1:275-282

Raudsepp-Hearne C, Peterson GD, Bennett EM (2010a) Ecosystem service bundles for analyzing tradeoffs in diverse landscapes. Proc Natl Acad Sci 107:5242-5247

Raudsepp-Hearne C, Peterson GD, Tengö M, Bennett EM, Holland T, Benessaiah K, MacDonald GK, Pfeifer L (2010b) Untangling the environmentalist's paradox: why is human well-being increasing as ecosystem services degrade? Bioscience 60:576-589

Reed J, van Vianen J, Foli S, Clendenning J, Yang K, MacDonald M, Petrokofsky G, Padoch C, Sunderland T (2017) Trees for life: the ecosystem service contribution of trees to food production and livelihoods in the tropics. For Policy Econ 84:62-71

Reyers B, Folke C, Moore ML, Biggs R, Galaz V (2018) Socialecological systems insights for navigating the dynamics of the anthropocene. Annu Rev Environ Resour 43:1-23

Rockström J, Steffen W, Noone K, Persson Å, Chapin FS, Lambin EF, Lenton TM, Scheffer M, Folke C, Schellnhuber HJ, Nykvist B, de Wit CA, Hughes T, van der Leeuw S, Rodhe H, Sörlin S, Snyder PK, Costanza R, Svedin U, Falkenmark M, Karlberg L, Corell RW, Fabry VJ, Hansen J, Walker B, Liverman D, Richardson K, Crutzen P, Foley JA (2009) A safe operating space for humanity. Nature 461:472-475

Rodríguez JP, Beard TD Jr, Bennett EM, Cumming GS, Cork SJ, Agard J, Dobson AP, Peterson GD (2006) Trade-offs across space, time, and ecosystem services. Ecol Soc 11(1):28

Schmitt CB (2006) Montane rainforest with wild Coffea arabica in the Bonga region (SW Ethiopia): plant diversity, wild coffee management and implications for conservation. Cuvillier Verlag, Göttingen

Schmitt CB, Senbeta F, Woldemariam T, Rudner M, Denich M (2013) Importance of regional climates for plant species distribution patterns in moist Afromontane forest. J Veg Sci 24:553-568

Schwartz MW, Brigham CA, Hoeksema JD, Lyons KG, Mills MH, van Mantgem PJ (2000) Linking biodiversity to ecosystem function.pdf. Oecologia 122:297-305

Shackleton CM, Shackleton SE, Buiten E, Bird N (2007) The importance of dry woodlands and forests in rural livelihoods and poverty alleviation in South Africa. For Policy Econ 9:558-577

Shackleton S, Delang CO, Angelsen A (2011) From subsistence to safety nets and cash income: exploring the diverse values of non-timber forest products for livelihoods and poverty alleviation. In: Shackleton S, Shackleton CM, Shanley P (eds) Non-timber forest products in the global context. Springer, London, pp 55-81

Shumi G, Schultner J, Dorresteijn I, Rodrigues P, Hanspach J, Hylander K, Senbeta F, Fischer J (2018) Land use legacy effects on woody vegetation in agricultural landscapes of south-western Ethiopia. Divers Distrib 24:1136-1148

Shumi G, Dorresteijn I, Schultner J, Hylander K, Senbeta F, Hanspach J, Ango TG, Fischer J (2019a) Woody plant use and management in relation to property rights: a socialecological case study from southwestern Ethiopia. Ecosyst People 15:303-316

Shumi G, Rodrigues P, Schultner J, Dorresteijn I, Hanspach J, Hylander K, Senbeta F, Fischer J (2019b) Conservation value of moist evergreen Afromontane forest sites with different management and history in southwestern Ethiopia. Biol Conserv 232:117-126

Singh GG, Cisneros-Montemayor AM, Swartz W, Cheung W, Guy JA, Kenny T-A, McOwen CJ, Asch R, Geffert JL, Wabnitz CCC, Sumaila R, Hanich Q, Ota Y (2018) A rapid assessment of co-benefits and trade-offs among Sustainable Development Goals. Mar Policy 93:223-231

Sintayehu DW (2018) Impact of climate change on biodiversity and associated key ecosystem services in Africa: a systematic review. Ecosyst Health Sustain 4:225-239

Spellerberg IF, Fedor PJ (2003) A tribute to Claude Shannon (1916-2001) and a plea for more rigorous use of species richness and species diversity and the 'Shannon-Wiener' Index. Glob Ecol Biogeogr 12:177-179

Sunderland TCH (2011) Food security: why is biodiversity important? Int For Rev 13:265-274

Sunderland T, Powell B, Ickowitz A, Foli S, Pinedo-Vasquez M, Nasi R, Padoch C (2013) Food security and nutrition: the role of forests. Discussion paper. Bogor, Indonesia

Tilman D, Fargione J, Wolff B, D'Antonio C, Dobson A, Howarth R, Schindler D, Schlesinger WH, Simberloff D, Swackhamer D (2001) Forecasting agriculturally driven global environmental change. Science 292:281-284

Tilman D, Reich PB, Knops JMH (2006) Biodiversity and ecosystem stability in a decade-long grassland experiment. Nature 441:629-632

Tilman D, Balzer C, Hill J, Befort BL (2011) Global food demand and the sustainable intensification of agriculture. Proc Natl Acad Sci 108:20260-20264

Tscharntke T, Clough Y, Bhagwat SA, Buchori D, Faust H, Hertel D, Hölscher D, Juhrbandt J, Kessler M, Perfecto I, Scherber C, Schroth G, Veldkamp E, Wanger TC (2011) Multifunctional shade-tree management in tropical agroforestry landscapes-a review. J Appl Ecol 48:619-629 
Tscharntke T, Clough Y, Wanger TC, Jackson L, Motzke I, Perfecto I, Vandermeer J, Whitbread A (2012) Global food security, biodiversity conservation and the future of agricultural intensification. Biol Conserv 151:53-59

Tura HA (2018) Land rights and land grabbing in Oromia, Ethiopia. Land Use Policy 70:247-255

UN (2015) Transforming our world: the 2030 agenda for sustainable development. UN, Report No. A/RES/70/ 1. http://www.un.org/ga/search/view_doc.asp?symbol=A/ RES/70/1\&Lang=E

Wakjira TD, Gole WT (2007) Customary forest tenure in southwest Ethiopia. For Trees Livelihoods 17:325-338

Woollen E, Ryan CM, Baumert S, Vollmer F, Grundy I, Fisher J, Fernando J, Luz A, Ribeiro N, Lisboa SN (2016) Charcoal production in the mopane woodlands of Mozambique: what are the trade-offs with other ecosystem services? Philos Trans R Soc B Biol Sci. https://doi.org/10.1098/rstb. 2015.0315

Wu J (2013) Landscape sustainability science: ecosystem services and human well-being in changing landscapes. Landsc Ecol 28:999-1023

Yachi S, Loreau M (1999) Biodiversity and ecosystem productivity in a fluctuating environment: the insurance hypothesis. Proc Natl Acad Sci 96:1-6

Publisher's Note Springer Nature remains neutral with regard to jurisdictional claims in published maps and institutional affiliations. 